\title{
HOMEWARD BOUND: DOMESTIC SPACE, IDENTITY AND POLITICAL AGENCY IN MAYA ANGELOU'S AUTOBIOGRAPHY
}

\author{
AMAYA FERNÁNDEZ MENICUCCI \\ University of Alicante
}

\section{QUESTIONING SPACE CATEGORIES}

Maya Angelou's six-volume autobiography ${ }^{1}$ is cast across a variety of geographical spaces, from her native California to the small town of Stamps, in rural Arkansas, from the West coast to the Babel of New York, from the United States to Europe and Africa. It is the aim of the present article to explore the relationship established between the narrator's wandering across physical space and the process of self-construction along the narrative journey, by analysing spatial representation as configured through the constant interaction of physical, socio-cultural and political dimensions.

Theories of Diaspora have not been the first to acknowledge the coexistence and simultaneous interaction of such dimensions, but they have certainly proved necessary to take into account the individual's perception and representation of geographical space so as to explain the dynamism and ambivalence of their location within socio-cultural spheres of identification or exclusion. Social categories, cultural systems and political practices interweave interactive networks, which individuals cannot elude and which theories of self-construction cannot ignore, since «real lives are forged out of a complex articulation of these categories», as Avtar Brah points in her work Cartographies of Diaspora: Contesting Identities ${ }^{2}$. According to recent postcolonial feminist theories ${ }^{3}$, such complexity may be charted out in the same way that physical

1. Published in successive waves along more than forty years and constituted, in chronological order, by I Know Why the Caged Bird Sings, Gather Together in My Name, Singin' and Swingin' and Getting' Merry Like Christmas, The Heart of a Woman, All God's Children Need Travelling Shoes, and A Song Flung Up to Heaven.

2. BRAH, Avtar: Cartographies of Diaspora: Contesting Identities, London, Routledge, 1996, p. 102.

3. Mohanty, Chandra T.: «Introduction: Cartographies of Struggle: Third World Women and the Politics of Feminism,» in Ch.T. Mohanty, A. Russo \& L. Torres (eds.): Third World Women and the Politics of Feminism, Bloomington, Indiana University Press, 1991, pp. 1-47. MirzA, Heidi S. (ed.): 
spaces are represented and interpreted on geographical maps, stressing thus the existence of "a series of homologies between the spatial, symbolic and social orders ${ }^{4}$. It is in this sense that my analysis of Angelou's narrative will focus on the mechanisms through which the diverse representations of domestic space reflect different stages in the narrator's progress through life and depend on the specific position adopted by the individual within or against social structures. Moreover, since space in Angelou's narrative is conceived as a multilayered reality in which symbolic and social orders are inextricably linked with the material, her nomadic experience implies a dynamic approach to both geographical and social space, a perception of life as a journey across visible and invisible barriers, a voyage in which the changes undergone by physical landscapes match the changes to which the narrator's self is subject.

Precisely because of the fluidity with which both processes of space representation and self-definition take place, Angelou's construction of domestic space cannot be based on an opposition between public and private dimensions, but it is articulated through a dynamic process along which the individual's position is negotiated in relation to physical and symbolic collective spaces. Her representation of domestic space depends on its configuration as either a space of belongingness or a space of un-belongingness to a social context. Therefore, it is not constructed as an isolated physical dimension, separated from any external reality by a rigid material frame, but it is delimited by permeable boundaries which allow for a continuous osmosis between the inside and the outside. As Blunt and Rose argue:

"The definition of the private as a domestic space separate from the public world of commerce was rarely meaningful in black communities; to the extent that it did resonate, the private was understood as a place, often a neighbourhood, beyond everyday encounters with white racism». ${ }^{5}$

The socio-cultural barriers which precluded Afro-Americans' access to the space of visibility in politics, commerce, and work are structurally different from those which relegated white middle-class women to domestic, family space. Furthermore, domestic space in Angelou's works is used to negotiate the individual's location within micro-social, as well as macro-social structures, thus considerably enlarging its functional configuration from the exclusive reign of family life to a site of socio-political agency. This does not simply convey the idea that domestic space is a malleable reality to be rearranged according to the

Black British Feminism. A Reader, London, Routledge, 1997. Blunt, Alison \& Rose, Gillian (eds.): Writing Women and Space. Colonial and Postcolonial Geographies, London, The Guilford Press, 1994. ANG-LyGATE, Magdalene: "Charting the Spaces of (Un)location: On Theorising Diaspora,» in H.S. Mirza (ed.): Black British Feminism. A Reader, London, Routledge, 1997, pp. 168-186.

4. Moore, Harriet L.: Space Text Gender: An Anthropological Study of the Marakwet of Kenia, Cambridge, Cambridge University Press, 1988, p. 1.

5. Blunt, Alison \& Rose, Gillian: «Introduction: Women's Colonial and Postcolonial Geographies», in A. Blunt \& G. Rose (eds.): Writing Women and Space. Colonial and Postcolonial Geographies, London, The Guilford Press, 1994, p. 4. 
narrator's shifting experiences, but also that within domestic space individuals can construct their self-identity, a social community can assert their collective identity and political discussions and actions can take place in order to break into and deconstruct hegemonic institutions. Therefore, domestic space, on both a physical and symbolic level, contains and is identified with personal, communitarian and public space.

\section{DOMESTIC SPACE AS THE PLACE OF (UN)BELONGINGNESS}

"Until I was thirteen and left Arkansas for good, the Store was my favourite place to be. Alone and empty in the mornings, it looked like an unopened present from a stranger. Opening the front doors was pulling the ribbon off the unexpected gift. The light would come in softly (we faced north), easing itself over the shelves of mackerel, salmon, tobacco and thread. It fell flat on the big vat of lard and by noontime during the summer the grease had softened to a thick soup. Whenever I walked into the Store in the afternoon, I sensed that it was tired. I alone could hear the slow pulse of its job half done. But just before bedtime, after numerous people had walked in and out, had argued over their bills, or joked about their neighbors, or just dropped in "to give Sister Henderson a 'Hi y'all,'” the promise of magic mornings returned to the Store and spread itself over the family in washed life waves» ${ }^{6}$.

Her grandmother's General Store, with its small backrooms where the family slept and ate their meals, is the first space with which Maya feels identified. Indeed, not only does she describe it with longing tenderness, but she even talks of it as a living creature, awaking and falling asleep, working and resting in synchrony with family life: the Store actually represents her family's whole life. The process of identification with its spatial dimension begins, thus, with the assimilation of physical space to the function it has been assigned in everyday life: inside the front shop area, work is done, money is earned and people are met and talked to, while, in the rooms at the rear of the Store, food and night sleep are shared by the four members of the family. The fundamental social and physiological activities in their lives are all contained within the physical space of this or that room $^{8}$, while the Store, as a unity, contains all of them at once. Therefore, in the young girl's experience, the superposition of a symbolic dimension of space onto the physical one is a direct consequence of life being so inextricably linked to the space it takes place in, that both the former and the latter must converge into a single whole.

Identification between the space described in the quoted paragraph and the narrator, between the observed and the observer, is patent in the silent communication which the child establishes with the Store and which she

6. Angelou, Maya: I Know Why the Caged Bird Sings, London, Virago, 1984 (1969), p. 16. Henceforth, Caged Bird.

7. In order to distinguish the literary persona of the narrator from the author, I will refer to the former as Maya and to the latter as Angelou.

8. Except for the attendance of religious services, which, albeit is possibly considered by Maya's grandmother as the most important activity in people's lives, takes place outside the domestic sphere of the Store and falls outside the methodological framework of the present analysis. 
"alone could hear». A space belonging to, and also clearly identified with Maya's family transcends both its value as a physical reality and as a social space moulded around her family structure, to reach the ultimate significance of personal space. The intimacy of the child's relationship with the Store is rendered through the former's interpretation and articulation of the emotions oozing from the building: she alone understands it and gives it a voice, while, at the same time, the shop enables her to speak out her own sensations by projecting them onto its walls. Its personification originates from an act of imagination on behalf of the child, who places, upon the physical dimension of the Store, an image mirroring her inner emotional landscape. Thus, the Store portrayed in the fragment above is not her grandmother's Store, nor the same space as perceived by her brother Bailey or her uncle William, but her Store, constructed upon mutual reflections of the symbolic onto the physical. The existence of such reciprocity prevents the child's imagining of the Store from being merely an act of appropriation, but it constitutes the basis for a much deeper link binding the girl and the Store together: their belonging to each other: "[u]ntil we became familiar enough to belong to the Store and it to us, we were locked up in a Fun House of Things where the attendant had gone home for life»?.

The concept of belongingness is central to Maya's sketching of the Store as her first home, more so since the place could not be defined as private, following the traditional understanding of the term. It is a place where "numerous people» wandered in and out of from early morning till late afternoon ${ }^{10}$, where neighbours lingered for some chat, «barbers sat their customers in the shade of its porch, and troubadours [...] leaned across its benches and sang their sad songs»" ${ }^{11}$. The "alone and empty» Store that the narrator defines as an "unopened gift», comes to life when its front doors are opened to the public. Its configuration as Maya's personal space of belongingness is not limited to a one-to-one intimate dialogue; on the contrary, the Store assumes its full identity in the eyes of the little girl when it bestows its gifts on village people and foreigners, on family members as well as on strangers. What makes Maya think of the Store as home is not, therefore, the exclusiveness of an enclosure to which admittance is barred from whomever is not recognized as a rightful member of the family circle. Even though the place is outlined in the quoted paragraph as an independent world within the world, it was, nonetheless, «built in the heart of the Negro area, and it became the lay center of the activities in town $»^{12}$. Its physical boundaries allow for an osmotic stream to flow in and out, the openness of the place contrasting against the selectiveness of the Western bourgeois domestic space. Maya's first home is not limited to domestic space, but it spreads out to include the space of work, social

9. Angelou, Maya: I Know Why..., op. cit., p. 8.

10. Ibid., pp. 8-10.

11. Ibid., p. 7.

12. Ibid. 
intercourse, and community life, all of which calls for a different definition of the very idea of «home».

The Store, that unfamiliar "Fun House», becomes home when Maya and her brother eventually recognise it as "familiar», as part and parcel with family life. It is, therefore, the establishment of kinship links with her grandmother and uncle that brings Maya to acknowledge the space they occupy, first as an extension, and later, as the physical embodiment of the concept of family itself. At the same time, the process of symbolic construction of the child's identity begins with the conception of family as an extension of the individual self, whose specificity derives from and is determined by its interrelationship with the whole. The process of self-identification with the Store is, thus, a consequence of Maya's identification with her family: the net of blood-links and emotional interdependence conforms a space of belongingness which is extrapolated to physical space, so that it is through their identification with family space that both Maya and the Store acquire their full identity and can be said to mirror each other. In fact, if the Store constitutes the core of Maya's childhood, the heart and centre of the Store is Momma Henderson, who not only "had [the place] built» and "had owned [it] some twenty-five years»" but also communicates to the place she inhabits the centrality of her character inside the community. Maya's grandmother, is, at one and the same time, a caring othermother ${ }^{14}$ and a model of the "majesty ${ }^{15}$ of Black women ${ }^{16}$. She is a community mother, and a mother of the $\mathrm{church}^{17}$, a pillar in the Afro-American side of the rural Arkansas town, so that the fact that Maya is recognised as Sister Henderson's granddaughter places her not only within the circle of familiar space, but also at the very centre of the Black community. Like a stone dropped in water, the certainty of belonging to her grandmother creates a succession of concentric ripples which transmit the concept of belongingness to the Store, as well as to the neighbourhood.

Personal, family and community space contrive to participate of the same defining elements as long as the feeling of belongingness glues them together. Indeed, identification between Maya and physical space is torn away as soon as she leaves her grandmother's sphere to enter into that of her blood-mother, Vivian Baxter. Their first encounter takes place in her maternal grandparents' house, where Maya and her brother sat "on the edge of [their] seats in the overfurnished living room» ${ }^{18}$, and where Maya feels the icy sting of misrecognition:

13. Ibid.

14. Angelou, Maya: Singin' and Swingin' and Getting' Merry Like Christmas, London, Virago, 1985 (1976), p. 48.

15. Angelou, Maya: A Song Flung Up to Heaven, London, Virago, 2003 (2002), p. 211.

16. Angelou, Maya: I Know Why...s, op. cit., pp. 28-32.

17. Ibid., pp. 32, 45-46.

18. Ibid., p. 58 . 
«[Bailey] never shared the icy wind of solitude with me. She was his Mother Dear and I resigned myself to his condition. They were more alike than she and I, or even than he and I. They both had physical beauty and personality, so I figured it figured. [...] Our father left St. Louis a few days later for California, and I was neither glad nor sorry. He was a stranger, and if he chose to leave us with a stranger, it was all of one piece» ${ }^{19}$.

Unable to define herself as belonging to this beautiful woman she had no memory of, Maya senses the blank void of a domestic space which she does not belong to because she lacks the ability to mirror herself in her mother's face. Belongingness to a maternal figure is still central to the configuration of family space and to the subsequent creation of a personal bond with the physical space of residence, only, in this case, it is the idea of un-belongingness that determines space representation. Thus, the sense of alienation that emerges from the impossibility of recognising herself in her mother's features transcends to a domestic space which can be called a house, but not a home any longer:

"Moving from the house where the family was centered meant absolutely nothing to me. It was simply a small pattern in the grand design of our lives If other children didn't move so much, it just went to show that our lives were fated to be different from everyone else's in the world. The new house was no stranger than the other, except that we were with Mother ${ }^{20}$.

Sharing the same domestic space with her blood-mother does not make it a familiar space, as much as sharing life with Vivian Baxter does not turn her into Maya's mother. Identifying domestic space with personal space is not possible when self-identity is threatened by the chasm of symbolic orphanage and the thread of belongingness has been cut by the absence of mutual recognition. Domestic spaces are represented as precarious camping sites from which to move onwards in search of a true home. The idea of life as a chain of incessant movements is clearly stated in the passage above, uprootedness being conceived as an impending doom, as the watermark of Maya's very existence, just as the ambivalent movement between geographical and imagined landscapes is at the basis of the diasporic experience. The quest for a homeland as a process of selfdefinition is asserted even more clearly a little further in the text:

"As quickly as I understood that I had not reached my home, I sneaked away to Robin Hood's forest and the caves of Alley Oop where all reality was unreal and even that changed every day. I carried the same shield that I had used in Stamps: 'I didn't come to stay.' ${ }^{21}$

Space is not owned, but merely used to move on to the next stage in her life. What is more, her unequal experience of domesticity at her grandmother's and now at her mother's teaches Maya that home is a place defined by the who,

19. Ibid., p. 59 .

20. Ibid., pp. 66-67.

21. Ibid., p. 68. 
not by the where. Therefore, space will be used, from this moment onwards, to negotiate her un/belongingness to a collective identity and, ultimately to define her own individuality.

Thus, Maya's quest for her identity is paralleled by a winding journey through different houses, which, in the first place, will encourage her to search for any traces of her belongingness to the family clan. During her first sojourn at her mother's house in St. Louis, and the summer holiday spent at her father's house in Los Angeles, as well as during the successive periods in which she will lodge with Vivian in San Francisco, Maya will never cease to look for a way to bridge the distance which separates her from her kin. If she certainly fails at doing so as far as her relationship with her father goes, - «if I disappeared Dad would be relieved $\aleph^{22}-$, her relation to Vivian is much more complex. In a first stage, Maya assumes the role of a symbolic stepdaughter to her biological mother, thus positioning herself as an outcast excluded from the close relationship between Vivian and Bailey. Their closeness to each other occupied the central stage in the family drama, while "from the wings [Maya] heard and watched the pavane of tragedy move steadily towards its climax ${ }^{23}$. The choice of a spatial metaphor to convey the sense of her marginality in the family order, stresses the existence of a clear overlapping of physical and psychological space, as the narrator reaffirms later on, by stating that « $[\mathrm{t}]$ he house was smudged with unspoken thoughts and it was necessary to go to [her] room to breathe» ${ }^{24}$. Maya, who has "been left out of their power/love struggles, and forgotten on the sidelines $»^{25}$ is materially cornered in her room, alien to a house belonging to other people.

However, the absence of parental belongingness between Vivian and Maya enables the latter to establish a connection which, different as it were from the mother-daughter intercourse, constitutes a lasting point of reference for the narrator, who will always look at Vivian as a model of Black resistance and agency. "During this period of strain Mother and I began our first steps towards mutual adult admiration ${ }^{26}$, states the narrator, revealing the attainment of a reciprocal recognition as equal individuals and, what is more, as Black women. Thus, Vivian is not, at this point, a channel through which belongingness to blood ancestry may be obtained, but a model of Black womanhood linking Maya to her socio-cultural community and, so, to her ethnic ancestry. In the "smoke-filled dining room» $»^{27}$ of Vivian's boarding-house - «a fourteen-room typical San Franciscan post-Earthquake affair» ${ }^{28}$ located in the centre of «San Francisco's Negro neighbourhood ${ }^{29}$ - Maya "was introduced to the most

22. Ibid., p. 243.

23. Ibid., p. 250.

24. Ibid., p. 254.

25. Ibid., p. 251.

26. Ibid., p. 261.

27. Ibid., p. 214.

28. Ibid., p. 212.

29. Ibid., p. 205. 
colourful characters in the Black underground $»^{30}$. She experiences a domestic space which merges into community space, just as it did at her grandmother's Store. Once again, privacy is not a fundamental feature of Maya's domestic space. Instead, she finds the domestic and the communal concurring to weave the string of belongingness to a collective identity, that of the Afro-American community.

Years later, her perception of the domestic as the open threshold to a social context will be consciously affecting her choice of Accra, the capital of Ghana, as the place to locate her domestic sphere and, thus, to locate herself within the warm embrace of a social community she aspires to belong to. Maya will shift the object of her eagerness to belong from family space to ethnic space, but the functional centre from which to reach out into collective space will still be identified with the house.

«Each person had brought to Africa varying talents, energies, vigor, youth and terrible yearnings to be accepted. On Julian's side porch during warm black nights, our voices were raised in attempts to best each other in lambasting America and extolling Africa». ${ }^{31}$

Julian Mayfield's side porch is another transitional element connecting the inside of domestic space with outside of communitarian space. Just like Momma Henderson's porch, it is conceived as a platform from which individuals achieve visible status within the common ground of social structure, the only difference lying in the fact that in Stamps the porches and backyards are material vehicles for interpersonal encounters and mutual recognition as community members inside the framework of a micro-social system, whereas, in Accra, Maya and the rest of the Afro-American expatriates are attempting to make themselves visible in the macro-social cartography of Africa. Moreover, they raise their voices in an effort to be heard, thus opposing their silenced subaltern position within Northern American society against their hope to be recognised as legitimate members of the African macro-social landscape. Even when Maya's "living room had begun to compete with the Mayfield side porch for popularity ${ }^{32}$, the purpose of those meetings inscribed within the boundaries of domesticity are still the same: to negotiate the expatriates' location on the African socio-cultural map of belongingness: "[w]e had come home, and if home was not what we had expected, never mind, our need for belonging allowed us to ignore the obvious and to create real places or even illusory places, befitting our imagination $»^{33}$. What is especially relevant about Maya's reflection on the purpose of her sojourn in Ghana, is, in the first place, the fact that belongingness is not seen as something which the individual is

30. Ibid., p. 214.

31. Angelou, Maya: All God's Children Need Travelling Shoes, London, Virago, 1987 (1986), p. 18. Henceforth, All God's Children.

32. Ibid., p. 39.

33. Ibid., p. 19. 
born into, but as the product of the subject's own agency ${ }^{34}$, of the individual's ability to "create real or even illusory places». In the second place, domestic space is never a separate, totally autonomous dimension and by moving in and out of domestic space Maya secures or severes her bonds with a given socio-cultural space. In All God's Children, Julian Mayfield's or Maya's houses in Ghana are instrumental to their integration in African society. In The Heart of a Woman, Maya decided to leave a glamorous white neighbourhood and to begin "searching for another school and another house» because she and her son "needed an area where black skin was not regarded as one of nature's most unsighted mistakes ${ }^{35}$. Both episodes prove that domestic space is primarily represented as a site of either belongingness or un-belongingness to social contexts.

\section{DOMESTIC SPACE AS A SITE OF SELF-ASSERTION}

\subsection{A house of one's own}

The two most important female figures in Maya's life, Vivian Baxter and Momma Henderson, owned their own houses and businesses, they both ruled undisputed in their personal universe and were mistresses of their own fate ${ }^{36}$. It is not surprising, therefore, that domestic space in Angelou's narrative does not only represent the narrator's grade of participation of a collective identity, but embodies, as well, the individual's strife to acquire a distinct personal space and, consequently, a personal identity. Soon after her unexpected son was born, Maya decides that she "would quit the house, take a job and show the whole world [...] that I was equal to my pride and greater than my pretensions ${ }^{{ }^{37}}$. Subsequently, a transfiguration of the symbolic significance of domestic space takes place and, for the first time, it becomes primarily a space of self-assurance in which individuality could be sought outside the family network.

«I had rented a room (with cooking privileges) in a tall, imposing San Francisco Victorian and had bought my first furniture and a white chenille bedspread. God, but it looked like a field of tiny snow roses. I had a beautiful child, who laughed at seeing me, a job that I did well, a baby-sitter whom I trusted, and I was young and crazy as a road lizard. Surely this was making it $^{38}$.

34. See Eagleton, Mary (ed.): Feminist Literary Criticism. A Reader, London, Blackwell Publishers, 1996, pp. 342-345.

35. Angelou, Maya: The Heart of a Woman, London, Virago, 1986 (1981), p. 21.

36. In Momma Henderson Maya "saw only her power and strength» (Caged Bird, p. 45), and she talks of Vivian as "[her] beautiful mother, who ran business and men with autocratic power, taught [her] to row [her] own boat, paddle [her] own canoe, hoist [her] own sail. She warned, in fact, 'If you want something done, do it yourself'» (Angelou, Maya: Singin' and Swingin' and Getting' Merry Like Christmas, London, Virago, 1985 (1976), p. 14).

37. Angelou, Maya: Gather Together in My Name, London, Virago, 1985 (1974), p. 8. Henceforth, Gather Together.

38. Angelou, Maya: Gather Together in..., op. cit., p. 16. 
Motherhood, work and a space to herself constitute the three axis around which Maya's personal dimension will be articulated throughout the following autobiographical volumes. According to Mary Jane Lupton ${ }^{39}$ and Stephen Butterfly, "[c]ontinuity [along the texts] is achieved by the contact of mother and child» ${ }^{40}$. Domestic space may also be considered as a unifying element across the textual fabric, for its inherent precariousness is a coherent representation of the keep-on-moving nature of Maya's approach to life. Finally, the configuration of domestic space as personal space is tightly bound to Maya's definition of herself as a working subject. On the one hand, the joy of home-decoration is due to the material enactment of self-assertion on physical space, but, on the other hand, it derives from the awareness of the fact that a place of her own has been gained through hard work. Thus, the acquisition of personal space may not be set apart from her ability to find her own stance in what has traditionally been regarded as a public sphere. In other words, she delimits her personal dimension within both the domestic and the work sphere, untying personal space from a given material environment and, so, reaffirming her individual identity beyond the reductive boundaries of the private/public opposition. Indeed, the pride with which she undertakes the task of furnishing her rented room in the fragment above reappears, time and again, in every episode in which the narrator describes her conquest of a new personal space. Every time she succeeds in providing herself with financial and spatial independence, the process of turning a house into a home is described in full detail:

"The apartment was small and dark and humid, so I bought gallons of white latex paint and a stack of rollers and brushes. I painted every inch of visible wall and the entire floor bone-white. I went over the floor with a few coats of adobe enamel. [...] In Los Angeles I bought orange, rust and brown burlap and draped the material casually at windows. I made huge colorful floor pillows and piled them on the floor. Van Gogh and Matisse posters enlivened the walls.

I stacked painted wood planks and burned cheap candles in Chianti and Mateus wine bottles. When the melted wax nearly covered the bottles, I put fresh candles in them and placed them around the room for light and esoteric effect». ${ }^{41}$

With the money Maya has earned singing blues and calypso songs at a Hawaiian night club, she is not only able to support herself, but also to keep moving forward towards new experiences. With her son now a young adult finishing his studies in Ghana, Maya is free to choose the course of her life and she chooses to be on her own. Years have passed since she rented her first room but the urge to transform a neutral, alien space into her own has

39. Lupton, Mary Jane: "Singing the Black Mother: Maya Angelou and Autobiographical Continuity", Black American Literature Forum, 24: 2 (summer 1990), pp. 257-276.

40. Butterfield, Stephen: Black Autobiography in America, Amherst, University of Massachusetts Press, 1974, p. 213.

41. Angelou, Maya: A Song Flung Up to Heaven, London, Virago, 2003 (2002), p. 56. Henceforth, A Song. 
not diminished in the least. Moreover, the effort of active manipulation of space turns the anonymous flat into moulding material in her hands, into a pile of amorphous clay to be handled through the plastic experience of artistic creation. Walls and floors painted white become fresh canvasses on which the process of self-projection may begin; orange and rust and brown are splashed on the blank surfaces, which are no longer dead matter, but become alive -enlivened-as Maya imprints her identity on them. Like a picture looks back at its creator, inevitably mirroring whoever gave it its form, space is represented as an extension of the narrator's self. Space representation, however, is not limited within the bi-dimensional axes of a picture, as it may be the case with "Van Gogh and Matisse posters", on the contrary, it fully surrounds the observer, who is forced to enter the picture and turn around to take in each detail provided by the narrator: the pillows randomly thrust on the floor suggest the presence of people crouching on them, just as the numerous candles hint at a definite atmosphere of long intimate evenings. The flat is, therefore, carefully designed to be a scenario ready to be filled with actors, a candle-lit stage on which to perform a play whose script is still to be written, but whose tone has already been defined by Maya's conscious choice of hues and nuances. In other words, in this case domestic space is not only being deployed as a reflection of the narrator's subjectivity, but also as a perimeter within which to enact, to live that subjectivity.

Thus, even a rented place -and Maya will never buy a house, as far as the six volumes show-, even short-term lodgings which she does not, strictly speaking, possess, can be perceived as personal space, precisely because space is not merely laid out in physical terms, it is not a material commodity to be owned, bought and sold: space, according to Maya's experience, is there to be occupied, to frame a specific location of the subject within the mutable intersections of the social, cultural, political and psychological dimensions. Therefore, a change in the subject's position among such intersecting cartographies determines a change in the perception and representation of the space they occupy. Just as she used to employ her grandmother's or her mother's house to depict her stance in relation to family space and blood-ancestry, she now uses domestic space to materialise her search for self-assertion.

Furthermore, it may be interesting to compare how the same actions, the same attempts at turning alien space into her own, project different images of the narrator on the walls of domestic space, depending on her particular conception of the self at a given point in her life. For instance, in The Heart of a Woman, Angelou narrates her moving into one of the "[r]ed-roofed, Moorish styled houses nestled seductively among madrone trees in Laurel Canyon, the official residential area of Hollywood" ${ }^{42}$, because she "wanted desperately to live in the glamorous surroundings»" ${ }^{43}$. Here too she "painted the small house

42. Angelou, Maya: The Heart of..., op. cit., p. 4.

43. Ibid., p. 5. 
a sparkling white ${ }^{44}$, but she does not give us a precise vision of the interior of the house, as she does in the paragraph quoted before; instead, she focuses on the outside, on the flowers that "bloomed in a riot of crimsons, carnelian, pinks, fuchsia and sunburst gold» ${ }^{45}$, and the same self-satisfaction with which elsewhere she minutely describes her house furnishing, is now extended to her "handsome dated automobile» ${ }^{46}$ :

"The car, a sea-green, ten-year old Chrysler, had a parquet dashboard, and splintery wooden doors. It could not compete with the new chrome of my neighbors' Cadillacs and Buicks, but it had an elderly elegance, and driving in it with the top down, I felt more like an eccentric artist than a poor black woman who was living above her means, out of her element, and removed from her people» ${ }^{47}$.

Maya is exploring Los Angeles as a place where her artistic aspirations might come true, since, even though "she accepted as fictitious the tales of amateurs being discovered at lunch counters", she firmly believes that it is «important to be in the right place at the right time, and no place seemed so right to [her] in 1958 as Laurel Canyon ${ }^{48}$. Again, space is being given a value in accordance to her intentions and, again, it is being approached as a scenario in which she chooses to perform a certain role, in this case, that of an "eccentric artist». In contrast with the previous examples of Maya's use of domestic space as an oasis of individual independence, her small bungalow in Laurel Canyon is fundamentally a means to stand at the centre of an exterior reality. So, the description of domestic space is turned outwards, and, so, the focus of attention is shifted from the inner area of the house to the outer area of the car, a car which is convertible, thus allowing for external visibility, and mobile, so that it permits travelling around the social space of the neighbourhood. It may be said, therefore, that such a representation of domestic space does not include privacy among its outstanding features, just as neither her grandmother's nor her mother's houses were rendered as private, separate areas, closed to any interaction with the social space of community. There is, however, a relevant difference between the Hollywood bungalow and the houses Maya knew during her childhood: while in the latter the social space of the Black community entered the domestic, in the former it is domestic space that is outstretched towards the neighbourhood.

This fact shows, in the first place, that a dichotomist approach to space, as forced by the application of the private/public opposition, is not viable in Angelou's disposition of spatial representation. Moreover, it may also be argued that, as much as the categories of inside and outside are relative, personal space -as defined by the quest for self-assertion- can also be extended beyond the limits of domesticity, so that self-definition is actually worked out anywhere

44. Ibid., p. 6.

45. Ibid., p. 5.

46. Ibid., p. 6.

47. Ibid.

48. Ibid., p. 5. 
in particular, and everywhere in general. Indeed, Maya is willing to seek her identity as an artist and a professional subject in an environment which she explicitly considers "above her means», and "removed from her people», thus placing herself outside both ethnic and class categories of belongingness. Social space is still represented through patterns of (un)belongingness, but personal space moves across frontiers because self-identity is not simply sought in relation to "her people», to her original community, but is also negotiated against the other. Consequently, it might be deduced that personal space is the journey itself: a work in progress, a dynamic reality that crosses geographical, socio-cultural and symbolic landscapes, not rooted to any, but experiencing them all. Since a journey can be defined as a succession of different locations of a given subject, personal space is the result of Maya's synchronic perception and interpretation of specific spaces as seen from the diachronic point of view of autobiographical narrative. To understand Maya's acquisition of identity is to follow her along the path she has been tracing in time and space.

\subsection{Space-acquisition through social networks}

Regarding domestic space as a locus of self-determination, I have mentioned so far three points of inflection in Maya's progression through her quest for subjectivity. The fourth domestic space to be represented as an extension of a self-constructed, individual identity, triumphant in its freedom, but still growing in its self-assurance, is also the last house to be rented by the narrator in Angelou's autobiography.

"I had wanted a flat in a brownstone, or at least a large apartment in one of the older buildings on Riverside Drive. Life offered me a one-bedroom apartment in a brand-new building on Central Park West. It was painted white, and its best feature was a long living room with big windows and a view of the park.

The place was clinical and so different from what I wanted that I thought bad fortune had caught me and I would be forced to live, at least for a while, in a cold and sterile environment. But life proved itself right and me wrong. Friends began giving me fine things for the apartment». ${ }^{49}$

On a first reading, a somewhat odd fact meets the eye: a white-walled apartment is perceived as "clinical, cold and sterile», whereas the "bone-white», or even the "sparkling white» walls in previous houses had been painted by the narrator herself. If white is the chosen colour to enlighten a small, dark flat in Los Angeles, it is significant to notice how a luminous, large-windowed apartment in Manhattan is interiorised as a hostile environment. Of course, in this case Maya has not had the chance to choose that colour, so whiteness is represented as an imposed feature and not as a consequence of an act of self-projection, of the subject's agency. However, its emptiness is no longer faced as a tempting canvass on which she might draw her blue-print, but as a threatening blankness, a mute mirror where she cannot recognise herself.

49. Angelou, Maya: A Song Flung Up..., op. cit., p. 137. 
This may be considered as further evidence of the fact that the representation of physical space is relative to the subject's interiorised perception of material reality and outward projection of their psychological situation. Nevertheless, it is also necessary to include the social environment that surrounds the domestic to understand fully what causes Maya's distress at finding herself inhabiting this «brand-new» apartment. During her sojourn in the candle-lit apartment, she had chosen before-hand the neat working-class neighbourhood as an ideal location for «its rightness of place $»^{50}$. In the case of the Los Angeles bungalow, she had "desperately" wanted to be in the middle of a white upper-class community. Now she finds herself unexpectedly placed at the very heart of an urban area which many Afro-Americans might consider as "enemy's territory» ${ }^{51}$. She has been persistently looking for her place in an area, the Upper West End and ends up somewhere completely outside her personal map of both the City and her life. Her new location makes her feel displaced, thus highlighting the influence that social environments exert over domestic space, which is never described without some explicit mention of the social micro-cosmos in which it is inserted. Moreover, domestic space is often chosen because of its social frame $e^{52}$, so that domestic space is but a marker of Maya's choice of locating herself in a definite socio-cultural setting.

The means by which such an alien space is turned into her own comes as a surprise to Maya: «[f]riends began giving me fine things for the apartment». She realises that social space is essentially constructed over a net of interpersonal relationships, and is not necessarily enclosed in a rigid physical delimitation -such as those barring a ghetto-, and, at the same time, she becomes aware of the fact that she is already placed at the centre of a well-spread web of interrelationships, so that wherever her house might happen to be, it will always be standing in the middle of a space of belongingness. Her friends, that is to say, those people whose intercourse she had chosen of her free will, are the basis for a truly personal space to be constructed upon, for not even bloodlinks nor the bonds of a collective cultural heritage can beget a space so deeply her own as the links which she herself has tied.

"As soon as it became known that I had an empty apartment, I began to receive good and even great furniture. A desk came from Sylvia Boone, who had just returned from Ghana. The composer Irving Burgee, who had written calypso songs for Harry Belafonte, was the most financially successful member of the Harlem Writers Guild, and when he heard that I had a new apartment, he gave a sleek table and an upholstered chair». ${ }^{53}$

50. Ibid., p. 54 .

51. Angelou, Maya: The Heart of..., op. cit., p. 155.

52. Angelou, Maya: The Heart of..., op. cit., pp. 5, 21, 139; All God's Children..., op. cit., p. 4; A Song Flung Up..., op. cit. pp. 54, 137.

53. Angelou, Maya: A Song Flung Up..., op. cit., p. 138. 
Ghana, where Maya had found her ancestral roots; Harlem, where she had discussed and produced literature, and led political activism; the echo of the calypso songs with which she had earned her living for many years and had introduced her into the fertile ground of Afro-American theatre: three essential aspects of Maya's identity -which she had been trying to define during all her life- are reunited into a single domestic space through a net of solidarity she herself had been interweaving along her journey. Her African, Afro-American and artistic identities are no longer the bits and odds of a fractured self, but a whole reality bound together by her belongingness to a social context she had chosen for herself and had patiently built throughout the years. It is the sudden awareness of her having earned both a collective identity and an individual one of her very own doing, that transforms the Central Park West "sterile apartment» into "[her] home» ${ }^{54}$ and into a triumph of her struggles for selfassertion.

\section{DOMESTIC SPACE AS A SITE OF POLITICAL AGENCY}

\subsection{The march and the conquest}

«Everyone [in the Killens' family] except Jon, whose nickname was Chuck, talked incessantly, and although I enjoyed the exchange, I found the theme inexplicably irritating. They excoriated white men, white women, white children and white history, particularly as it applied to black people.

I had spent my life on city front steps, in country backyards, kitchens, living rooms and bedrooms, joining in and listening to the conversations of black people, but I had never heard so much attention given to the subject of whites». ${ }^{55}$

So far in Maya's experience, the act of tale-telling as a verbal process of Black identity construction, has always taken place at a safety distance from the space defined by "whitefolks" identity. Those conversations inside Black domestic space have been intended to reinforce the image of a collective identity, while maintaining the rigid social barriers at the other side of which lays "whitefolkstown"56. "In fact», Angelou writes, even in their absence [whitefolks] could not be spoken of too harshly unless we used the sobriquet 'They' ${ }^{57}$. Physical and social segregation reflects itself on the symbolic space of language, which avoids approaching openly and closely what lays beyond their communitarian territory, since doing so would be equivalent to stepping over visible and invisible barriers and out into "enemy's territory». Therefore, when Maya, just landed at New York and staying temporarily at the Killens', finds herself constantly pushed into passionate debates on whiteness, she is taken aback by the transgressiveness of such acts, which implied a continuous

54. Ibid., p. 142.

55. Angelou, Maya: The Heart of..., op. cit., p. 32.

56. Angelou, Maya: I Know Why..., op. cit., p. 24.

57. Ibid., p. 46. 
trespassing to alien space. The domestic space of her friends' house, the «roomy brownstone in Brooklyn $»^{58}$, is transfigured by such discourses and turned into a political space where, whatever the initial topic of conversation might be, «in minutes [they] were persistently examining the nature of racial oppression, racial progress and racial integration ${ }^{\prime 5}$. This points at a further development of the function assumed by domestic space in Angelou's narrative: it does not simply represent the locus of identity-construction by identification with a social community of belongingness, or by opposition against a social context of otherness; it is not solely a crucial knot that holds together the social network delimiting community space; it is not only a site of resistance against hegemonic discourses, but a space of active political agency spreading towards the very centre of the dominating system. Indeed, domestic space is being used as a springboard into outer space, into a social dimension which exceeds the limits of segregated space and might be conceived as the heart of public space: the political arena.

"The Cultural Association for Women of African Heritage had its second meeting at Abbey's luxury penthouse apartment on Columbus Avenue. [...]The Charter, as drawn up by Sarah Wright and signed unanimously by the membership, stated that since the entire power of the United States was arrayed in fury against the very existence of the Afro-Americans, we, members of the CAWAH, would offer ourselves to raise money for, promote and publicize any gathering sincerely engaged in developing a just society ${ }^{60}$.

What were spontaneous outbursts of political consciousness at the Killens' have now become, a hundred pages later, a clearly defined, structured organisation for political activism. Physically located within the boundaries of domestic space, a group of Afro-American women are actually proposing to face "the entire power of the United States»: the constraining walls of "Abbey's living room»" ${ }^{61}$ are outstretched to embrace a larger space, that of "a just society». Moreover, the proverbial privacy and intimacy offered by a bourgeois, "luxury», apartment is thus being employed to give public visibility - "publicize»- to a collective that is geographically spread all over the country. The "Columbus Avenue» apartment is configured, therefore, as a space open both to the entire geographical extension of the United States, as well as to its global social landscape. Domestic space is being employed to address two social realities at the same time, that of the Afro-American community and that of the dominant "whitefolks", which both extend further beyond the material enclosure of Abbey's penthouse apartment, and which both occupy radically opposed physical and social dimensions. Consequently, domestic space is represented here as a site for the overcoming of those social and

58. Angelou, Maya: The Heart of..., op. cit., p. 31.

59. Ibid., p. 33.

60. Ibid., p. 143.

61. Ibid., p. 143. 
physical frontiers, an open ground where both communities might stand face to face. The "sobriquet 'They'" is no longer needed because Maya and the other members of the CAWAH are now addressing a you directly.

This confrontation, articulated on the abstract plane of the association's charter, will soon be transferred upon the material dimension of urban space through an overt act of defiance of physical barriers. After hearing of Patrice Lumumba's murder, Maya will turn CAWAH's general statement of principles and intentions into a concrete course of action which will both embody the passage from political awareness to political agency, and the egression from a segregated spatial dimension and into the domains of hegemonic power.

"After a short, fierce talk, our decisions were made. On Friday, we would attend the General Session of the United Nations. We would carry black pieces of cloth, and when Adlai Stevenson started to make his announcement on Lumumba's death, we six women would use bobby pins and clip mourning veils to the front of our hair and then stand together in the great hall. [...] If men joined us, we would make elasticized arm bands, and at the proper moment, the men could slip the black bands up their sleeves and stand with the women» ${ }^{62}$.

When «about ten women met at [her] house» to discuss Lumumba's death, their purpose was to do "something large enough to awaken the Black American community in New York" ${ }^{63}$ : domestic space is once again turned into a threshold leading to the public dimension of politics, it is a space where a strategy is forged which will open the path to an actual conquest of forbidden land. Therefore, the meeting at Maya's house subverts the physical and social configuration of domestic space by using it as the starting point of a march that will push open the frontiers between "the black American community" and the power fortress of the city of "New York", that will cross the heart and core of the United States of America right into the centre of the United Nations. The intimacy provided by domestic walls, the safety of a refuge removed from the inquiring gaze of the public, are the least interesting aspects of domestic space for a group of women who are not only struggling to open the eyes of their ethnic community, but also determined to place it under the sight of the whole world in the "great hall» of the United Nations. Indeed, when the members of CAWAH met at Abbey's house on that Friday morning to complete the last preparations, the penthouse apartment is described as "a flurry of action» ${ }^{64}$, suggesting an embryonic image of "the black throng» that awaits in front of the United Nations building, "packed together on the sidewalk» and spilling «out into the street ${ }^{65}$. The house full of women «busy, drinking coffee, laying the veils in one box, talking, putting the arm bands into another box ${ }^{66}$ has been consciously chosen to be the first step of a march which will be first invading

62. Ibid., p. 148.

63. Ibid., p. 146.

64. Ibid., p. 153.

65. Ibid., p. 154.

66. Ibid., p. 153. 
the General Assembly, where «seventy-five black people were mixed among the whites ${ }^{67}$, then flowing outwards again, where "thousands of people circled the street and all of them were black ${ }^{68}$, and finally marching through $43 \mathrm{rd}$ and $46^{\text {th }}$ streets up to the Associate Press building and the Belgian Embassy. Besides, Maya and Abbey Lincoln had previously been to Harlem to «let some folks [...] know what [they] intended to do ${ }^{69}$ : the homage to the African civil rights fighter has been laid out as a route through black community space and into "whitefolkstown", from an inclusive domestic space out to exclusive urban landscapes, through the United States and into the international community. Subsequently, the active commitment of a handful of women meeting within a domestic sphere begets a protest march which floods the City's institutional area and physically conquers a space belonging to the ruling elite.

As we have already seen in Maya's construction of her personal dimension, space is outlined as a chain of successive locations within social networks, and, specifically, the space of political agency is marked by the marchers' footsteps across a variety of grounds -still characterised as spaces of belongingness, such as Harlem neighbourhood, or un-belongingness, like New York midtown streets-, so that it does not coincide with any determined spatial outset. On the contrary, political space can be cut out of any physical and social setting, precisely because it is defined by affirmative action on physical and social structures either by identification or opposition. Thus, domestic space is but the initial stage in an ongoing process of political assertion which is meant to move onwards across and in-between socio-cultural crevices.

\subsection{Come home where you belong}

Political agency as a space stretched along a marching line in perpetual movement appears again in All God's Children, and again it is begot within domestic space. Gathering as usual at Julian Mayfield's house in Accra, Ghana, the Afro-American expatriates are informed of an upcoming protest "march to Washington, D.C., to be led by Martin Luther King Jr.. ${ }^{70}$. The immediate recognition of the Afro-American community as their own real space of belongingness is the spark that sets fire to the casual atmosphere of a dinner among friends, replacing it with the eagerness of an activists' political meeting.

"Someone made the suggestion that although we were radicals, as Black Americans we should support our people in the States and form a march sympathetic to the Washington march. As products of a picketing, protesting era, we unanimously and immediately agreed. Of course, we would march on the American Embassy with placards and some appropriate shouts $»^{71}$. [emphasis added]

67. Ibid., p. 157.

68. Ibid., p. 154.

69. Ibid., p. 148.

70. Angelou, Maya: All God's Children..., op. cit., p. 121.

71. Ibid., p. 123. 
Even though "homesickness was never mentioned in [their] crowd $»^{72}$ and "under no circumstances did [they] mention [their] disillusionment at being overlooked by the Ghanaians ${ }^{73}$, each one of the exiles at Julian's house is aware of the fact that "the entrance of a few Black Americans» in the country "went largely unnoticed ${ }^{74}$. Domestic space is not simply being altered by the sheer force of political action and turned into a site of political agency, but it is also re-presented as a space where the aching bonds with their community of birth are healed. Having shifted their location on a geographical plane, their relation to place has undergone a radical change: what had been for years their place of origin, the absent space of a mythical there, that is, the ancestral landscape of their Mother Africa, is now a tangible reality, a presence articulated on the 'here and now', whereas "Houston and Macon, Little Rock and St. Louis, Harlem and Chicago's south side ${ }^{75}$ are now painted in the émigrés minds with the vivid colours of an imagined and much longed 'back there', as their eyes "often ached for those familiar sights" ". Therefore, Julian's house is functioning primarily here as a space where individuals locate themselves within the circle of a collective identity, as it is clearly evidenced by the fact that, despite their being "radicals", they would support a political act they do not agree with because, "as Black Americans", they feel the urge to show their share in a collective identity. Domestic space is not standing any more on African ground, but it is, at one and the same time, a dimension of its own -removed from the Afro-American community by geographical distance and from Ghanaian society by cultural distance-, and a space tightly connected with both Africa and the States because, inside it, each individual is able to negotiate their position in relation to either. The house is fundamentally perceived as the locus where the individual's progression through any other space is planned, where the individual's identification with any social structure is defined or rejected, where, in short, geographical, political, social and cultural space is mapped out and the self's route through intersecting dimensions is outlined. The house is more than a delimited space, it is the open gate to an unlimited extension of continuous spaces.

If Maya's personal space is marked by her incessant travelling, the space of political agency is defined by an unrelenting collective march, which begins at home and is headed home: "we marched and sang thinking of home and the thousands who were marching in Washington, D.C.» ${ }^{77}$. Even though Maya and her friends, "the Revolutionist Returnees " ${ }^{78}$, have spent years trying to step into the picture of a welcoming Mother Africa they had been dreaming of in the

72. Ibid., p. 120.

73. Ibid., p. 19.

74. Ibid., p. 22.

75. Ibid., p. 120.

76. Ibid.

77. Ibid., p. 125.

78. Ibid., p. 126 
States, the awareness has slowly emerged that, although the African continent is their ancestral home, their condition as displaced subjects provides them with a complex conception of the idea of a home of their own, which is not so much anchored to a geographical context, but rather to a social community they belong to. Notwithstanding their common heritage and their shared condition as objects of hegemonic oppression, Africans and Black Americans are set apart by the experience of a forced Diaspora, as it is stressed by the use of the phrase "our people» in the quoted text. Indeed, the final goal of the programmed marched is not a Ghanaian institution; the "Revolutionist Returnees» are not aiming at making themselves visible on African space: they are marching towards the "American Embassy", in a symbolic, parallel march to Washington, D.C., the centre of American hegemonic institutions.

At this point in Maya's quest for a space of self-assertion and belongingness to a community, it is by locating herself in a dimension of political agency that she resumes her journey home. Indeed, her encounter with Malcolm X and her active involvement with his political struggle provide Maya with the last tiles to complete the picture of a home she has not reached yet, but whose location she is now aware of.

"When he [Malcolm X] sat with me after a long day of interviews and meetings, he was a big brother advisor, suggesting that it was time for me to come home. 'The country needs you. Our people need you. Alice and Julian and Max Bond and Sylvia, you should all come home. You have seen Africa, bring it home and teach our people about the homeland.' $)^{79}$

The living room where Maya and Malcolm sat «in the late evenings» $»^{80}$ is no longer holding a political meeting in which the activist "addressed a shocked and attentive audience ${ }^{81}$, as it was often the case during Malcolm's sojourn in Accra; the house is no longer "filled with expatriates eager to meet and listen to him, who sat on chairs, stools, tables and hunched on the floor, excited into a trembling silence ${ }^{82}$. The atmosphere is now intimate and loaded with the unspoken certainty that the bonds which unite them both to the AfroAmerican community are symbolically identical to and as strong as the blood links that draw a brother and a sister together. Thus, domestic space is once again the physical embodiment of a metaphysical space of belongingness in which community and family space are superposed to conform an image of home. Nonetheless, this image would not be complete if we did not consider the political implications of Malcolm's suggestion to "come home». Political agency, in fact, is not absent from the scene and, despite the lack of an audience in the room, Malcolm's words are still pointing at a determined public: "our people». Going back «home» is, therefore, seen as a mission whose aim is to

79. Ibid., p. 139.

80. Ibid.

81. Ibid., p. 129.

82. Ibid., p. 128. 
«teach our people about the homeland", to help their community to build themselves a home and a path to reach it. Inside the domestic setting of the living room an image of home is being constructed which comprehends the said superposed dimensions of ethnic and blood belongingness, but also those of political action and homeward marching. In fact, the term home in Malcolm's speech is used to refer not only to the geographical space of the United States of America, but also, and above all, to the socio-cultural space occupied by the Afro-American collective, so that their «home» is their people. On the other hand, the term homeland is referring to Africa, as a land as well as a cultural reference of a common origin and a shared heritage for both the inhabitants of the continent and for the subjects of the Diaspora. Then, "home» and "homeland" are concepts clearly distinguished by the speaker, and, nevertheless, they are both necessary to define the political, socio-cultural and geographical space of belongingness, visibility and agency, which is the end of Malcolm and Maya's endeavour. There is no "home» without an original, larger and common "homeland» to come from, and there is no meaning in identifying with a «homeland» if there is no «home» to go to.

The quest for self-identity which began at Stamps has been constructed along a winding path, getting into and out of spaces of belongingness, and ultimately seeking the home which Maya had found herself denied in her mother's house. The quest for collective identity and political assertion, arisen at the Killens' house in New York, is also cast across geographies of exclusion and identification, and is, indeed, intended to take the Afro-American community home. The fact that both quests share the house/home binomial, as respectively their starting point and final goal, evidences the existence of a common denominator in the construction of Maya's identity as an individual and as a member of a community, while, at the same time, it is suggestive of a conception and subsequent representation of domestic space which eludes traditional parameters of privacy and publicity and whose physical and symbolic configuration is inextricably linked to the negotiation of both individual and collective identities.

Finally, the distinction between the concept of house and that of home allows the narrator to conceive the latter as a dimension larger than the former, subverting any fixed and rigidly framed conception of domestic space and transforming her nomadic experience of geographical space into a continuous opportunity for personal and collective progress beyond physical, socio-political and cultural barriers. Indeed, the closing scene of $A$ Song Flung Up to Heaven takes place in her mother's house, where for the first time she had consciously felt homeless, and where she still seems to be homeward bound, for the last line in Angelou's narrative is also the first one in I Know Why the Caged Bird Sings: "' $[w]$ hat you looking at me for. I didn't come to stay" ${ }^{83}$. The autobiographical journey is thus endless since it merges with the beginning of the quest for a

83. Angelou, Maya: I Know Why..., op. cit., p. 3; and A Song Flung Up..., op. cit., p. 212. 
home, but is also infinite since the very idea that Maya "didn't come to stay" implies the intention to keep in constant progression, a conception of life in which the individual as well as the community must «rise and prepare to move on and ever on ${ }^{84}$. If the concept of home represents the space where individual and collective identities are defined and asserted, and the process of identity construction takes places through an endless journey, then home is not a fixed goal: it is progress. It is the unstoppable individual journey and collective march. She refuses, therefore, to consider her movement across socio-physical spaces as headed to a Promised Land, a mystified space of ownership and attainment of a stable identity; instead, she represents geographical and social landscapes as spaces where self-identity and collective assertion are subject to an endless progression and blessed with the chance of continuously reaffirming their will to be. Space is the rimless map where journeys are traced and Maya's home is her freedom to choose her own route.

\section{BIBLIOGRAPHY}

Angelou, Maya: I Know Why the Caged Bird Sings, London, Virago, 1984 (1969).

- Gather Together in My Name, London, Virago, 1985 (1974).

- Singin' and Swingin' and Getting' Merry Like Christmas, London, Virago, 1985 (1976).

- The Heart of a Woman, London, Virago, 1986 (1981).

- All God's Children Need Travelling Shoes, London, Virago, 1987 (1986).

- A Song Flung Up to Heaven, London, Virago, 2003 (2002).

ANG-LyGate, Magdalene: "Charting the Spaces of (Un)location: On Theorising Diaspora", in Heidi S. Mirza (ed.): Black British Feminism. A Reader, London, Routledge, 1997, pp. 168-186.

Blunt, Alison \& Rose, Gillian (eds.): Writing Women and Space. Colonial and Postcolonial Geographies, London, The Guilford Press, 1994.

Blunt, Alison \& Rose, Gillian: «Introduction: Women's Colonial and Postcolonial Geographies», in Alison Blunt \& Gillian Rose (eds.): Writing Women and Space. Colonial and Postcolonial Geographies, London, The Guilford Press, 1994, pp. 1-25.

BraH, Avtar: Cartographies of Diaspora: Contesting Identities, London, Routledge,1996.

BuTTERFIELD, Stephen: Black Autobiography in America, Amherst, University of Massachusetts Press, 1974.

Eagleton, Mary (ed.): Feminist Literary Criticism. A Reader, London, Blackwell Publishers, 1996.

HarawaY, Donna: Simians, Cyborgs, and Women: The Reinvention of Nature, London, Free Association Books, 1991.

Ноокs, Bell: Talking Back: Thinking Feminist, Thinking Black, Boston, South End Press, 1989.

Hill Collins, Patricia: Black Feminist Thought: Knowledge, Consciousness, and the Politics of Empowerment, New York, Routledge, 2000.

IfeKWUNIGWE, Jayne O.: «Diaspora's Daughters, Africa's Orphans? On Lineage, Authenticity and 'Mixed Race' Identity", in H.S. Mirza (ed.): Black British Feminism. A Reader. London, Routledge, 1997, pp. 127-152.

84. Angelou, Maya: A Song Flung Up..., op. cit., p. 212. 
Homeward Bound: Domestic Space, Identity and Political Agency...

Lefebvre, H. (Donald Nicholson-Smith, transl.): The Production of Space, Oxford, Basil Blackwell, 1991.

LuPTON, Mary Jane: «Singing the Black Mother: Maya Angelou and Autobiographical Continuity», Black American Literature Forum, 24: 2 (summer 1990), pp. 257-276.

Mirza, Heidi S. (ed.): Black British Feminism. A Reader, London, Routledge, 1997.

Mohanty, Chandra T.: "Introduction: Cartographies of Struggle: Third World Women and the Politics of Feminism», in Ch.T., Mohanty, A. Russo \& L. Torres (eds.): Third World Women and the Politics of Feminism, Bloomington, Indiana University Press, 1991, pp. 1-47.

Moore, Harriet L.: Space Text Gender: An Anthropological Study of the Marakwet of Kenia, Cambridge, Cambridge University Press, 1988.

Persram, Nalini: "In My Father's House Are Many Mansions: The Nation and Postcolonial Desire», in H.S. Mirza (ed.): Black British Feminism. A Reader, London, Routledge, 1997, pp. 205-215.

PonZAnesi, Sandra: «Diasporic Subjects and Migration», in G. Griffin \& R. Braidotti (eds.): Thinking Differently. A Reader in European Women's Studies, London, Zed Books, 2002, pp. 205-220.

SPIVACK, Gayatri Ch.: «Poststructuralism, Marginality, Postcoloniality and Value», in P. Mongia (ed.): Contemporary Postcolonial Theory. A Reader, London, Arnold, 1996, pp.198-222.

YounG, Lola: "What is Black British Feminism?», Women: a Cultural Review, Vol. 11, n 1 2, (2002), pp. 45-60. 